\title{
A HERMENEUTICS OF THE KINGDOM OF GOD IN THE CONTEXT OF ARMED CONFLICT IN MINDANAO
}

\author{
Jerson B. Narciso
}

\author{
| College of Theology \\ Central Philippine University \\ Iloilo City, The Philippines
}

\begin{abstract}
:
This study attempts to come up with a contextual theological understanding of the biblical concepts of the Kingdom of God in the light of the armed conflict in Mindanao. It seeks to understand the roots and causes of conflict in Mindanao (hermeneutical situation), into which the meaning of the biblical message of a peaceable kingdom is interpreted and understood in a meaningful manner. Taking into account the current socio-political, economic and cultural realities that contribute to the ongoing armed conflict in Mindanao, this study raises the issue of how the kingdom of God which embodies God's love, peace, liberation and justice should be understood and concretized in a way that it could inform and influence the different religious groups and organizations involved in the Mindanao peace process. This attempt for contextualization is based on the principle that theological formulation in the context of conflict in Mindanao, can only be meaningful and intelligible if it reflects critically on the lived-experiences that is shared by different Muslim and Christian communities in Mindanao, especially the poor and marginalized masses in their search for well-being and self-determination.
\end{abstract}

Keywords:

hermeneutics - Kingdom of God - biblical concept • armed conflict • Mindanao • economic transformation • socio-cultural transformation • political \&o structural transformation 


\section{Introduction}

The armed conflict in Southern Philippines has continued for more than four centuries and is considered one of the world's "longest" and "bloodiest" running armed conflicts. ${ }^{1}$ It is also known as the "largest and most persistent armed conflict in Southeast Asia." "The conflict has affected not only the people in Mindanao but also the entire Philippine society. It resulted in the destruction of properties and livelihood, displacement of thousands of families, deaths of thousands of combatants from both sides, and innocent civilians including women and children killed in the crossfire. ${ }^{3}$ It also contributes significantly to the political and economic instability of the country. ${ }^{4}$

The conflict has a long historical root that goes back to the Spanish and American colonial rules and the Muslims' continuing struggle for autonomy and self-determination in Mindanao. The struggle for selfdetermination of the Moro people has its origin in their aspiration for freedom and independence from Spanish and American rules and is fed by the perceived failure of the state to address their continuing experiences of impoverishment, social and cultural discrimination, and political injustice. The widespread and persistent government military offensives in Mindanao supported by American troops in the name of "war on terror" gives rise to more violence and armed conflict.

Since the outbreak of war between the government troops and the Moro National Liberation Front (MNLF) in the early 1970's, the Philippine government has maintained its strong militaristic and integrationist approach in resolving the conflict. The peace process has always been derailed by charges and countercharges of ceasefire violations that result in the usual collapse of peace agreements between the Philippine government and Muslim liberationist groups, and in the change of government's policy from negotiation to total war against the Moro National Liberation Front (MNLF), Moro Islamic Liberation Front (MILF), and the Abu Sayyaf Group (ASG). ${ }^{5}$

Muslim combatants and paramilitary groups such as the MNLF, MILF and the Abu Sayyaf Groups (ASG) also continue with their militant activities against the government. Capitalizing on the frustrations of Muslims brought about by their continuing marginalization, militant Muslims have adopted a more aggressive and radical stand against 
government policies and actions. The government is also viewed by Muslim militants as a threat to the Muslims' struggles and aspirations for independence and self-determination. They believe that their rights and existence are being denied by the government; that they have no control over their destiny, and they can be destroyed any time. With that, they are likely to escalate radicalism as they struggle to protect themselves and to pursue their rights in aggressive ways. ${ }^{6}$

\section{Biblical Concepts of the Kingdom of God (Old and New Testament Concepts)}

The theme, "kingdom of God", is central to the Biblical message. Biblical scholars are in agreement that the term is pregnant with meanings and there are varied ways of interpreting the concept based on some very specific contexts. ${ }^{7}$ For the purposes of this study, three aspects of the interpretation of the biblical concept of the Kingdom of God are being emphasized as follows:

\section{Theo-political}

First, the kingdom of God is conceived in the Bible as a theopolitical reality. The kingdom describes the very nature of God as King (melek) and Ruler over His people. While the specific term 'kingdom of God' is "virtually absent from the Old Testament", this does not negate the fact that the notion of the kingship and reign of God is present all throughout the Old Testament as expressed repeatedly in the phrase, "the Lord reigns." In fact, God's kingship is a dominant and recurring theme in the Hebrew Scriptures. ${ }^{10}$ Thus, the basic concepts behind the metaphor "kingdom of God" are undoubtedly present in the Old Testament.

In the New Testament usage, "kingdom" is the usual translation of the Greek basileia, signifying the king's being, nature and state. Like the melek in the Old Testament, one could find the close affinity of king and kingship in the meaning associated with kingdom. A separate partition between this two interrelated terms if not impossible will definitely destroy the essential meaning of each word. The kingdom is the expression of the King's dignity and power in the territory he rules. ${ }^{11}$ In modern Greek, "kingship", "royal dominion," or "reign," are present in basileia. What the Old Testament canons have (Hebrew and Aramaic originals and the 
LXX, including the Rabbinic writings) like the kings dignity and power predominating in melek is also true in the New Testament. ${ }^{12}$

Israel's nomadic times as tribes and how God accompanied them in their struggles, later with their Exodus from Egypt and the Mt. Sinai event molded her concepts about God as Ruler and King. ${ }^{13}$ This shows the close affinity between the concept of God's kingship and the experience of God in Israel's history which is very critical to the Hebrew understanding of God's character. Israel's series of experiences of Yahweh's intervention from times past up to the revelation of God's name through Moses have contributed a lot in their particular comprehension of Yahweh as King later on. ${ }^{14}$ Yahweh's revelation of His name as the Great "I AM" was understood in His Being and His working, as a name that denotes action that brings about goodness and blessings to His people. ${ }^{15}$

In the entire history and experience of Israel as a nation, God as the ruling King is affirmed as the ruling Lord, ${ }^{16}$ and an All-embracing One. ${ }^{17}$ Yahweh's Sovereignty acted with power of which the Old Testament writers were amazed, leads them to portray Him as the hope and comfort of the weak and marginalized. God is described as the One who has passion for justice and for the liberation of those in bondage, and this image is reflected in the Exodus accounts and the rest of the Pentateuchal and prophetic witnesses to the event. ${ }^{18}$

In many instances, God as King is portrayed as one who cares for the humbled poor and the oppressed (anawim ${ }^{19}$ ). The anawim is set against the wicked (reshaim), the oppressors who possess wealth and power and all those who take advantage of the vulnerability of the poor. ${ }^{20}$ The appellation "King" was applied to Yahweh on the basis of the saving events that Israel experienced and attributed to Yahweh. The notion came to see Yahweh as the one who had dominion or lordship over it and its history. ${ }^{21}$ This concept of Yahweh's dominion over Israel was later on expanded to cover all peoples and nations. ${ }^{22}$

\section{The Kingdom as God's Salvific and Liberative Act in Human History}

The Exodus event is one striking and central historical event in the life of Israel which shows God's liberating activity in the world and His special concern for the poor and the oppressed. The sufferings and oppression that the Israelites had suffered in the land of Egypt is 
described in the early chapters of the book of Exodus: repression ${ }^{23}$; humiliations ${ }^{24}$ slavery $^{25}$; forced labor and alienated work. ${ }^{26}$ Thus, exodus had to be remembered and re-enacted in the cult and tradition of Israel as the central theme of liberation and a powerful testimony of God's liberating character. ${ }^{27}$ The exodus event is also regarded as "the heart" of the Old Testament story and is pivotal for the rest of the Old Testament history and the faith that it witnesses to. ${ }^{28}$

God's gratuitous liberating act in the life and experience of Israel was to be honored and remembered faithfully by commitment and acceptance of the requirements of the covenant initiated by God and accepted by Israel. This commitment concerns not only fidelity to the one true God, but also a commitment to social obligations that must be observed among the people of the covenant. These social obligations are regulated in particular by what has been called the right of the poor. ${ }^{29}$ The gift of freedom from bondage in Egypt and the Promised Land, and the gift of covenant in Sinai and the Ten Commandments ${ }^{30}$ are therefore "intimately linked to the practices which must regulate, in justice and solidarity, the development of Israelite society." ${ }^{31}$ In view of the fact that Yaweh is a Liberator God, the Israelites were commanded to become guardians of justice and defenders of the weak and the oppressed.

To the Israelites, exodus was always an event that reminds them of Yahweh's gracious liberating act in human history and gives them the assurance that the God who delivered them out of bondage in Egypt will always be a liberator and savior God who will save His people from all forms of oppression and enslavement. ${ }^{32}$ This living reminder is enshrined in the basic premise of the preamble of the Ten Commandments, "I am the Lord your God who brought you out of the land of Egypt, out of the house of bondage", ${ }^{33}$ and in the Hebrew tradition of celebrating the Sabbatical and Jubilee Year, ${ }^{34}$ which refer to favors done to the peasants, the poor, the slaves and the oppressed.

Scholars generally agree that the central theme in the life, ministry, and teaching of Jesus is the kingdom of God. ${ }^{35}$ His parables are frequently introduced "explicitly or implicitly" as examples of the kingdom. ${ }^{36}$ The beatitudes include numerous references to the ethical requirements of the kingdom. The Lord's Prayer welcomes the advent of the kingdom and Jesus' answers to human questions are often couched in kingdom 
language. ${ }^{37}$ Debates on what exactly Jesus meant by the kingdom has continued down through centuries until the present. However, it appears clearly that Jesus' vision of the kingdom echoes the vision of Isaiah. Centuries before Jesus, Isaiah was projecting his dream of a salvation to come. Quoting the prophet Isaiah in the gospel of Luke, Jesus summarizes his identity and mission in these words:

"The Spirit of the Lord is upon me, because he has anointed me to preach good news to the poor. He has sent me to proclaim release to the captives, and recovering of sight to the blind, to set at liberty those who are oppressed, to proclaim the acceptable year of the Lord." 38

The mission of Jesus is to proclaim the Kingdom of God-the coming of final and definitive salvation. Like Isaiah, Jesus proclaims that the arrival of the kingdom is salvation and that the kingdom has the decisive connotation of liberation. This liberation was demonstrated in the words and deeds of Jesus: "blinds recover their sights, captives released, lame walk, hungry were fed, and the dead were being brought back to life." Jesus' mission statement i.e., proclaiming liberty and announcing the favorable year of the Lord reechoes the language of the Old Testament Jubilee year.

The kingdom of God is the transformation of an evil and oppressive situation. Jesus proclaimed and demonstrated the kingdom of God in the midst of those who were despised by society and segregated from its life. ${ }^{39} \mathrm{He}$ spoke against economic structures that created and perpetuated hungry masses. He fought against an elite aristocracy -the chief priests of the temple hierarchy, wealthy landowners, merchants, tax collectors, teachers of the law who out of their extravagance have reduced the masses to poverty and indignity. ${ }^{40}$ Many of the parables of Jesus were directed against abusive landowners who took advantage of the poor farmers who were gradually losing their small piece of land because of their debts. Tax collectors and estate owners took possession of the land of peasants who continued to accumulate outstanding debt. Often the peasant family would end up trapped in the plot, working as day laborers for the wealthy and absent landholders. ${ }^{41}$

\section{The Kingdom of God is Universal and Inclusive}

The eschatology of Israel is the result of her awareness of God moving 
in history. ${ }^{42}$ This dynamic understanding of God's active participation in human history involves not only the history of Israel but of the whole humankind. It involves not only the liberation and restoration of Israel but of all those who are afflicted and oppressed.

Amos prophesied of the imminent return and restoration of the exiles to their homeland. But the prophet added a new twist and challenge to the old exclusivistic claims of the Exodus traditions. He brought in a much broader consciousness and spoke in a radically inclusivistic tones of the experience of freedom and restoration as an event that is experienced not only by the people of Israel but by all those whom God has favored with a blessing of a new land and freedom from deprivation. ${ }^{43}$ God is a God who is not to be exclusively claimed by Israel for themselves alone. Yahweh is a God of the nations and other peoples who were oppressed and exploited. God's presence is boundless and universal: "Heaven is my throne, and earth my footstool. Where will you build a house for me? Where shall my resting place be? All these are my own making and these are mine." ${ }^{44}$ Thus, there was a significant move from an exclusivistic, narrow nationalistic perspective to a much broader faith perspective and attitude that includes consideration of other peoples, a consideration of their own struggles, their own histories, and their own traditions.

The Exodus event in this respect becomes a thematic key towards a more inclusive, more accepting faith perspective that became very important in Israel's attempt to reconstruct her faith relationship with Yahweh. Exodus in that sense was just one among other Exoduses God has conducted with other peoples. This universalistic view of God's liberative act is best expressed in the following prophetic declaration of Amos:

"He who builds his lofty palace in the heavens and sets its foundation on the earth, who calls for the waters of the sea and pours them out over the face of the land--the LORD is his name. Are not you Israelites the same to me as the Cushites? declares the LORD. Did I not bring Israel up from Egypt, the Philistines from Caphtor and the Arameans from Kir? " 445

The universal and inclusive character of the kingdom of God goes against absolutism and exclusivism that sets one religion superior than the other and thereby promote antagonism, hatred and division among different peoples. Here, the Biblical concept of the universal and all- 
embracing nature of the kingdom of God provides a foundational basis for an inclusive, accepting, and redeeming attitude that should characterize the relationship between Christians and Muslims in Mindanao.

Traditionalist theology maintains the narrow concept of the reign of God as synonymous or identical with the church or Christianity. A careful study and analysis of the meaning of the Kingdom of God however casts serious theological questions on "whether 'God's reign should be limited to the hope of Israel, and in its historical realization in the world, to Christianity and to the church." ${ }^{46}$ Or, should it be understood in a much wider sense to include "others?" in view of the biblical witness that the reign of God is a universal reality "which extends well beyond the confines of Christianity and the church?" 47 "If God's Kingdom is inclusive and universal, how do Christianity and other faith traditions relate respectively to live out the values of this universal kingdom? Do Christians and the others belong equally to the fulfilled reign of God?" 48

Karl Rahner has expressed the same conviction that God's kingdom is not confined within the limits of Christianity and the church: that the different religious traditions contain "supernatural, grace-filled elements," and that other faith traditions and communities are also "members of the Kingdom of God already present as a historic reality." ${ }^{49}$ In spite of their different religious peculiarities, "people of faith already belong together to the Reign of God and are already in communion in the reality of the mystery of salvation even if there remains between them a distinction at the level of the "sacrament", that is, the order of mediation of the mystery." 50

Dupuis believe that the words "communion" and "sharing" characterize God's Kingdom, that the reality of the reign of God is "already shared together" by different faith traditions in mutual exchange, and that Christians and others "build together the Reign of God each time they commit themselves of common accord in the cause of justice, each time they work together for the integral liberation of each and every human person, structures and systems, and especially for the liberation of the poor and the oppressed." ${ }^{51}$ 


\section{Implications of the Biblical Concepts of the Kingdom of God to the Problem of Armed Conflict in Mindanao}

Here, we see that a contextual reading of the biblical text provides an operative framework within which Christians could make sense of the meaning of the kingdom of God in the current socio-political and economic situations in Mindanao. If the kingdom of God means God's rule which is characterized by justice, freedom, equality and peace as chronicled in God's continuous liberative activity to free His people from dehumanizing powers, then, what does it mean to proclaim and participate in the kingdom of God in the midst of socio-economic and political inequalities in Mindanao?

How does the biblical concept of the theo-political character of the kingdom of God which describes God's compassionate rule and righteous governance relate to the struggles of the marginalized Muslim communities in Mindanao? Is God's rule present in the struggles of the Bangsamoro people for freedom and self-determination in Mindanao? If God is on the side of the weak, the poor, and the oppressed as revealed in the way He manifests Himself in the lived-experiences of His people, then, what is God doing in the midst of social, political, cultural and economic injustice in Mindanao? If the kingdom of God refers to His liberative acts all throughout human history with different peoples at different times and places, then, what does it mean to proclaim the peaceable kingdom of God in such a historical milieu where unjust political and economic order exist such as in Mindanao? These are crucial questions that we should seriously consider if we are to make positive impact in the Mindanao peace process. If God's Kingdom is inclusive and universal, how do Christians and other faith communities relate respectively to live out the values of this universal kingdom? Do Christians and the others belong equally to the fulfilled reign of God?

Based on the biblical message, I believe that building the kingdom of God in the context of Mindanao means proclaiming and living out God's compassionate rule and righteous governance, to work for the establishment of an equitable socio-economic order. It means, working for the emancipation and liberation of the poor and transforming evil in all its forms. To affirm the universality of God and His kingdom is to affirm that He is present in every human condition and that God is 
concerned about the whole human family regardless of race, culture and creed. This principle promotes the idea of acceptance, openness and complimentarity which means, Christians and Muslims in Mindanao are supposed to acknowledge their unique differences with a sense of acceptance and respect ${ }^{52}$, and never use them as a ground for discord but an opportunity to compliment and cooperate with one another for their common good.

One vital question is where does the church locate itself in the current socio-political and economic crises in Mindanao? Is the church on the side of the poor, or, has it become (as it was in the past) a legitimizer of the status quo and oppressive social order?

Certainly, the contributions of the different religious organizations in the Mindanao peace process should not be overlooked or undermined. Small scale livelihood projects, financial assistance to displaced families in times of war, "peace zones", "peace sanctuaries", peace-building programs, interfaith dialogues, position papers and calls for a negotiated peace agreement between disputing parties are important and have served their purpose. However, in as far as how these programs have addressed vital issues of equitable distribution of land and other resources, wider participation of the marginalized masses in the political processes, and the establishment of a just social order in Mindanao, remains uncertain. As it appears, there is still much work to be done in terms of finding concrete steps and solutions towards the improvement of economic and political conditions in Mindanao.

\section{Ministry Recommendations}

If Christians believe that their duty is to proclaim and help build the kingdom of God in which there is love, justice, peace, and compassion for the weak and the powerless, how are they supposed to translate this conviction into concrete plan of action/s that will contribute towards peace and development in Mindanao?

Given the current socio-economic, cultural and political injustice reigning in Mindanao, this study recommends the following political agenda (based on the above interpretation of the kingdom of God) for genuine and lasting peace in Mindanao: 


\section{Economic Transformation}

The conflict in Mindanao has its roots in the socio-economic marginalization of the Moro people. Their economic displacement is largely a historical outgrowth and the cumulative effect of a long process of discriminatory laws, policies, and programs, including development programs. The most visible sign of displacement of the Moro people including other indigenous and minority groups in Mindanao has something to do with their rights to land. The historic discriminatory land policies and legal statutes favoring Christians and large scale multi-national agriculture and mining corporations during the American colonial rule and the Philippine Government's policies of resettlement of Christians to Mindanao had resulted in a slow but sure abrogation of traditional Moro property rights and their eventual marginalization from mainstream economic growth and development. ${ }^{53}$

Statistics show that in spite of the government's comprehensive land reform program, millions of people especially the marginalized and poor Muslims in Mindanao remain landless. In many parts of Mindanao, vast tracks of land are owned by multinationals and super rich who dominate the economy and making the poor poorer. ${ }^{54}$

The state of land distribution in the Philippines shows that land ownership is concentrated in the hands of a very few people. Statistics show that 45 per cent of the country's agricultural land is owned by only five per cent of the total landowning families. Another document pointing to the glaring inequality of land ownership notes that roughly 80 per cent of the total cultivated land is controlled by only 20 per cent of the landowning families. Not only do few landowners own large tracts of lands, they also possess the most fertile lowlands. Multinational corporations such as, DOLE, Del Monte, and United Fruits utilize more than 80 percent of the country's most fertile lowlands for export crops. ${ }^{55}$

In this particular context, peace in Mindanao would mean, inclusion of key issues of reparations, economic redistribution, and land reform. The economic displacement of the Moro people must be at the center and not the periphery of the peace and development challenge in Mindanao. Peace-building program in Mindanao should first and foremost, address the land problem. Current development approaches of assisting minority Muslims with micro projects such as livelihood programs, community 
assistance, rehabilitation projects for victims of war and other dole out economic approaches are mere palliative since they do not address vital issues and the real roots and causes of poverty in Mindanao. Concrete steps are to be done to break the chains of oppressive economic structures through the implementation of genuine land reform program.

To address the issue of landlessness which significantly contributes to poverty among the Muslim masses, the Philippine government needs to legislate laws to regulate and limit the size of the family holding of land and in the process implement land redistribution program to cater to the needs of the landless masses in Mindanao. No peace can occur in a situation where big and powerful land lords continue to dominate the economic and political sphere at the expense of the weak and the poor. Addressing the problem of economic marginalization in Mindanao also requires that the government should create laws and implement inclusive and far reaching economic programs that are accessible to address the economic well being and dignity of the poor and the marginalized. Laws and policies need to be established to prevent and penalize abusive and exploitative economic practices, and ensure the protection of the poor and the oppressed, provide equal economic and political access, establish mechanism for consultative and participatory leadership where the marginalized could take part in the decision-making process to determine their future and destiny.

\section{Socio-Cultural Transformation}

Another important issue that must be addressed in relation to the search for peace in Mindanao is the continuing socio-cultural marginalization of the Moro people. Stereotypical negative concepts of Muslims as "savage", "uncivilized", and people of "inferior race" that has been institutionalized since colonial era, and has been reinforced by subsequent Filipinization program of the Philippine government has not ceased to disturb and affect significantly Christian-Muslim relations in Mindanao. Despite the Muslims' resistance, the central government insists on its integrationist policy which seeks to mainstream minority Islamic and other indigenous cultures into the majority Filipino culture. Muslims find themselves at odds with what constitutes the "national identity" of the majority lowland Christian population who in their view had been 
assimilated into the cultures and ways of the two major colonial regimes.

The inculcation and imposition of the majority Filipino culture is interpreted by many Muslims as an attempt to eradicate Moro culture and identity. The Moro people have been longing for the recovery not only of their lost causes but also the restoration of their dignity and worth as a people. Equitable sharing of wealth, political and social justice are the recurring themes that Muslims in Mindanao have been clamoring for up until now. Conflict resolution or transformation in Mindanao is the process of addressing these causes and working with those concerned to redefine relationships and bring about a change in the conflict context.

To address the problem of conflict in Mindanao, a culture of peace and mutual recognition of both Islamic and Christian values and culture, has to sink deep into the social fabric where cultural openness, social unity and pursuit of peaceful means to resolve conflict is appreciated and practiced by all. Social and cultural reforms are one of the key ingredients of lasting peace and development in Mindanao. Without them the issues that underlay the breakdown of peace and social order will continue to exist. Peace and development in Mindanao needs a sustained effort at social justice, good governance, and corporate social responsibility. To achieve mutual respect and appreciation between and among Muslims and Christians in Mindanao, relationship building across sectoral, social, cultural and religious divides is of primary importance.

Solution to the Mindanao problem is anchored on the creation of a national consciousness sensitive to cultural diversity. This means, the government and the majority Filipino populace must recognize the value and distinctiveness of Moro cultures and identities. Consequently, it also means that the government should adopt culturally-sensitive policies that seek to honor and preserve Islamic cultural heritage. The government must through its Department of Education (DedEd) and Commission on Higher Education (CHED), review and effect changes in the history curriculum in so far as the history of Islam in the Philippines is concerned, to correct negative images of Muslims and emphasize positive and unique cultures and values that they share towards peace and development.

The government also needs to formulate laws and policies that promote cultural understanding and ethnic awareness. Giving Muslim Mindanao autonomy and addressing their socio-economic problems are not enough. 
Their cultural identities must be recognized and accommodated by the state. The Moro people must be free to express these identities without being discriminated against in other aspects of their lives. In a nutshell, cultural liberty is a human right that must be enjoyed by the marginalized Moro masses - and thus worthy of state action and attention.

\section{Political and Structural Transformation}

Political domination and marginalization, graft and corruption, clan and patronage politics, and fraudulent electoral systems which perpetuate traditional political elites in power remain to be one of the major causes of conflict and violent confrontations in Mindanao. The government has failed to make concrete political actions to address the aspirations of the poor and marginalized majority Muslim masses. Instead, it caters to the whims and caprices of Christian and Muslim powerful elites who are taking advantage of their positions at the expense of the weak, and therefore, privileging only the dominant segment of society. The dominance of the powerful and the marginalization of the poor and powerless has been the pattern of relationship that characterizes the Philippine society.

The pacification and demobilization approaches employed by the government which seeks to address the conflict by cooptation of leaders and followers through the offer of positions, or livelihood, or integration has left the deeper roots of the conflict unaddressed. Obviously, power and resources are concentrated in the hands of a few political elites while the masses (mostly Muslims) are being pushed to the periphery of human existence. Philippine politics has been reflective of extensive patron-client networks wherein access to political power is greatly dependent on one's loyalty to those who already wield it. Once in office, politicians are often able to perpetuate themselves in power, and as soon as their term limits end, they easily move on to occupy some other positions. This results to only a few political dynasties competing for political power leaving the weaker segments of society powerless. ${ }^{56}$

The ties of traditional Muslim elite leadership with the central government has kept the marginalized Muslims' struggles unaddressed and deprived them of their right to self-determination. It has been noted by a number of analysts that the same traditional local elites amass contemporary political power in the form of elected positions by entering 
into a political economic bargain with the national political elites to barter Internal Revenue Allocations (IRA) from the central state treasury in exchange for delivering votes and security for the competing national and local political actors. ${ }^{57}$

Exercise of absolute authority by traditional political elites are made possible not only by political patronage from the national government, but also by "laws and regulations permitting the arming and private funding of civilian auxiliaries to the army and police; lack of oversight over or audits of central government allocations to local government budgets; the ease with which weapons can be imported, purchased and circulated; and a thoroughly dysfunctional legal system." ${ }^{58}$ The question is how can the government prevent the emergence of overly dominant political clans and warlords who set their own rules and use their power to exploit and oppress the weak and the poor?

Precisely, the Mindanao problem is a political and structural problem. Thus, it requires a political and structural solution as key dimension. No significant changes in so far as addressing the problem of conflict in Mindanao can take place unless policies change; and for these change to happen, the country's politics must change toward more participation, involving especially the marginalized sectors in making decisions that affect them. Any social, economic, and political strategy that attempts to effectively address problems of conflict in Mindanao will have to be comprehensive, inter-sectoral, communal, and participatory.

It has been observed that, despite numerous development projects and financing programs that have been channeled through different government agencies since early 1970 s to solve the problem of poverty in Mindanao, the economic and living conditions of the Moro people has not significantly changed. This was mainly because of defective bureaucratic structures that were known for their graft and corruption. ${ }^{59}$ Obviously, social intervention and economic development devoid of appropriate and viable political structure is insufficient.

Concrete steps should be done to minimize (if not totally eliminate) rampant graft and corruption practices both in the higher and lower echelon of the government. This requires stricter and fuller implementation of anti-graft laws and their corresponding punishments as well as creation of preemptive structures such as "Graft watch" composed of highly credible 
representatives coming from the government, civic, business, political and religious sectors. The establishment of anti-graft measures is important not only to prevent corrupt and anomalous practices in the government, but also to ensure protection of the economic interests of the poor and the marginalized and to pave the way for economic progress.

The government also needs to develop massive and sustainable grassroots based programs of peace and development by establishing mechanisms that would enhance and ensure peoples participation, by initiating continuous and regular public consultations involving the poorest of the poor, the indigenous people, the women and the youth, and by making concessions not with the political elites but with the Moro masses who are the actual victims of oppression and marginalization in Mindanao.

God's will is peace, love, hope and justice. The situation of unpeace in Mindanao brought by the continuing oppression and marginalization of the weak and the poor is radically opposed and incompatible with the biblical vision of a just, humane and peaceful community where persons live with peace and dignity. This biblical vision must come in contact with the socio-cultural, economic, and political realities reigning in Mindanao.

In a nutshell, the peaceable kingdom of God as understood in the context of Mindanao, provides political and theological basis for asserting a notion of peace and justice, the content of which are defined in concrete socio-political, cultural and economic terms. There is a direct link between the theoretical concept of God as Liberator and Defender of the poor and the political, economic, and social injustice in Mindanao. This calls for moral and political responsibility to act responsibly on behalf of justice and freedom and to work towards the establishment of a just political, social and economic structure which is in harmony with the divine vision of a peaceable kingdom. ${ }^{60}$

\section{Bibliography}

Beasly-Murray., G.R. Jesus and the Kingdom of God. USA: William B. Eerdsmans Publishing Company, 1986.

Brueggeman, Walter. "Isaiah 40-66," in Westminster Bible Companion. Louisville, KY.: Westminster John Knox Press, 1998. 
Buber, Martin. Kingship of God. New York: Harper \& Row, 1967.

Darrot M., Bryant. Pluralism, Tolerance and Dialogue. Ontario: University of Waterloo Press,1989.

Dupuis., Jacques. Jesus Christ at the Encounter of World Religions. Maryknoll, New York: Orbis Books, 1991.

Dupuis., Jacques. Toward a Christian Theology of Religious Pluralism. Maryknoll, New York: Orbis Books, 1997.

Gutierrez., Gustavo. The Power of the Poor in History. Maryknoll, N.Y.: Orbis Books, 1989.

King Jr., Martin Luther. The Measure of Man. Philadelphia: Fortres, 1959.

Kittel., Gerhard. Theological Dictionary of the New Testament. Grand Rapids

Michigan: Wm B. Eerdsmans Publishing Company,1964.

Köhler, Ludwig. Old Testament Theology. Philadelphia: Philadelphia Westminster Press, 1957.

Kraybill B., Donald. The Upside Down Kingdom. Scottdale, Pa.: Herald Press, 1978.

Pannenberg, Wolfhart. Theology and the Kingdom of God. Philadelphia: Westminster Press, 1969.

Pixley V., George. On Exodus: A Liberation Perspective. Maryknoll, N.Y.: Orbis Books, 1987.

Preuss., Horst Dietrich. Jahweglaube und Zukunftserwartung. Stuttgart, Germany: Kohlhammer, 1968.

Rahner, Karl. "Christianity and the Non-Christian Religions", in Theological Investigations 5. London: Darton, Longman and Todd, 1966:115-34.

Ramakrishna, Kumar \& Tan, See Seng. After Bali the Threat of Terrorism in Southeast Asia. Singapore: World Scientific, 2003.

Santos, Soliman M. Dynamics and Directions of the Peace Negotiations Between the Philippine Government and the Moro Islamic Liberation Front. Quezon City, Philippines, 2004.

Sobrino, Jon. Jesus in Latin America. Maryknoll, New York: Orbis Books,1987.

Sobrino, Jon. Spirituality of Liberation. Maryknoll, New York: Orbis Books, 1988.

Swartley, Millard. Covenant of Peace: The Missing Peace $n$ the New Testament Theology and Ethics. Grand Rapids Michigan: William B. Eerdsmans Publishing Company, 2006. 
Trocmé, André. Jesus and the Non-violent Revolution. Scottdale: Herald press, 1973.

von Rad., G.F. Old Testament Theology 2. New York: Harper, 1965.

Wadi, Julkipli. The Moro Struggle and the Tenets of Islam in the Philippines. The Hague, the Netherlands: Institute of Social Studies, 2008.

Yoder., John Howard. The Politics of Jesus. Grand rapids, MI: William B. Eerdsmans Publishing Company, 1972.

\section{Endnotes:}

1 Philippine Free Press, May 27, 2000.

2 Samuel K. Tan, in Kumar Rama Krishna \& See Seng Tan, After Bali the Threat of Terrorism in Southeast Asia (Singapore: World Scientific, 2003) 98.

3 Ibid., 98

4 For example, the governments of Canada, Australia, New Zealand, the United Kingdom, and the United States have made periodic advisories that restrict travel of their citizens to Mindanao for "security" reasons. see "The Roadmap to More Foreign Investment", Manila: American Chamber of Commerce of the Philippines, Inc., March 2003.

5 For instance, Santos notes that from 1996 to 2000, the government and the MILF entered into a total of 39 peace agreements, joint communiqués, acknowledgments, and resolutions. However, throughout this period, no resolution was reached on substantive issues raised by the MILF. See Soliman Santos, Dynamics and Directions of the Peace Negotiations Between the Philippine Government and the Moro Islamic Liberation Front (Quezon City, Philippines, 2004) 6.

$6 \quad$ Ibid.

7 See Walter Brueggeman, "Isaiah 40-66," Westminster Bible Companion (Louisville, KY: Westminster John Knox Press, 1998).

8 Recent studies have provided answers to the issue of the "absence" of a direct phrase, "kingdom of God" in the Old Testament which raises the problematic question of how this metaphor was made prominent in the New Testament particularly in Jesus' understanding of the kingdom of God which is so central to his teachings and mission. One example of these recent contributions is Bruce Chilton's A Galilean Rabbi and His Bible and "Regnum Dei Deus Est". In his study of the Isaiah Targum, e.i., the Aramaic paraphrased translation of Isaiah, Chilton discovers that in several Isaiah texts (e.g., 24:23; 31:4; 40:9; 52:7) the Targum actually uses the exact phrase, "kingdom of God." See, Willard M. Swartley, Covenant of Peace: The Missing Peace $n$ the New Testament Theology and Ethics (Grand Rapids Michigan: William B. Eerdsmans Publishing Company, 2006) 15-16.

9 Swartley, ibid., 15.

10 Examples of which include Exod. 15:18; 1Sam. 8:7; Ps. 24:7-10; 47; 48:1-2; 74:1214; 84:3; 93; 95-99; 145:1;12-13; Isa. 43:15; 44:6.

11 Gerhard Kittel, Theological Dictionary of the New Testament (Grand Rapids Michigan: Wm B. Eerdsmans Publishing Company,1964) 579.

12 A. Deissmann, The Religion of Jesus and the Faith of St. Paul: "Kingdom or Sovereignty, 
Kingly Rule of God (London: Hodder and Stoughton, 1923) $108 \mathrm{ff}$.

13 G.R. Beasly-Murray, Jesus and the Kingdom of God (USA: William B. Eerdsmans Publishing Company,1986) 17.

14 H. D. Preuss, Jahweglaube und Zukunftserwartung (Stuttgart, Germany: Kohlhammer, 1968), $15 \mathrm{ff}$.

15 Ibid., $15 \mathrm{ff}$.

16 L. Köhler, Old Testament Theology (Philadelphia: Philadelphia Westminster Press, 1953) 143.

17 Martin Buber, Kingship of God (New York: Harper \& Row, 1967) 58.

18 Noriel C. Capulong, "The Bible in the Context of the Filipino Life and faith Today," a paper presented during the Genaro Diesto Jr. Memorial Lecture, Central Philippine University, Iloilo City, 14 June 2010.

19 The term anawim is often associated with the afflicted, the humbled, oppressed, lowly, subjugated and the poor. The root word is "anab" which means, the oppressed. For complete reference, see Exodus 22:25; Leviticus 19:10 and Deuteronomy 15:11.

20 Psalm 37:11. Note: all direct biblical quotations are taken from the New International Version (NIV).

21 Jon Sobrino, Jesus in Latin America (Maryknoll, New York: Orbis Books, 1987) 42.

22 Jeremiah 10:7.

23 Exodus 1:10-11.

24 Exodus vss.11-14.

25 Exodus 13:3; 20:2

26 Exodus 5:6-14.

27 Jorge V. Pixley, On Exodus: A Liberation Perspective (Maryknoll, N.Y.: Orbis Books, 1987) xiv.

28 Janzen in Swartley, op. cit., 15.

29 Deuteronomy 15:7-8.

30 Pope John Paul II refers to the Ten Commandments as laws that "constitute the indispensable rules of all social life." See John Paul II, Encyclical Letter Veritatis Splendor, 97: AAS85 (1993), 1209.

31 Pontifical Council for Justice and Peace, Compendium of the Social Doctrine of the Church (Makati: Word of Life Publications, 2004) 16, 17.

32 Gustavo Gutierrez, The Power of the Poor in History (Maryknoll, N.Y.: Orbis Books, 1989) 111-124.

33 Exodus 20:2.

34 Jubilee year celebrated the end of the week of sabbatical years or the end of seven, seven- year periods of time. Just as the Sabbath indicated the end of a week of days, the sabbatical year signaled the end of a week of years and the jubilee ended a week of sabbatical years. The jubilee was celebrated every fifty years and Sabbatical year was celebrated every seven years. For a detailed and complete explanation of the meaning of jubilee, see North (1976) 496.

35 John Howard Yoder, The Politics of Jesus (Grand rapids, MI: William B. Eerdsmans Publishing Company, 1972) 23.

36 Swartley, op. cit., 15

37 For a more elaborate discussions on the analysis of Jesus' understanding of the 
kingdom, see Wolfhart Pannenberg, Theology and the Kingdom of God (Philadelphia: Westminster, 1969).

38 Luke 4:18, 19.

39 Jon Sobrino, Spirituality of Liberation (Maryknoll, N.Y.: Orbis Books, 1988) 47.

40 Donald B. Kraybill, The Upside Down Kingdom (Scottdale, Pa.: Herald Press, 1978) 83.

41 André Trocmé, Jesus and the Non-violent Revolution (Scottdale: Herald press, 1973) 87 88.

42 G. F. von Rad, Old Testament Theology 2 (New York: Harper, 1965) 99-107.

43 Amos 9:7.

44 Isaiah 66:1-2.

45 Amos 9:6,7.

46 Jacques Dupuis, Toward a Christian Theology of Religious Pluralism (Maryknoll, New York: Orbis Books,1997) 332.

47 Ibid.

48 Ibid.

49 Karl Rahner, "Christianity and the Non-Christian Religions", Theological Investigations 5 (London: Darton, Longman and Todd, 1966) 121.

50 Jacques Dupuis, Jesus Christ at the Encounter of World Religions (Maryknoll, New York: Orbis Books, 1991) 346.

51 Ibid.

52 Harold Coward asserts that respect for other religious beliefs is the true basis of tolerance. Tolerance doesn't mean giving up one's critical awareness. It could mean honest constructive criticism and learning from one another. See Coward in Darrot M. Bryant, Pluralism, Tolerance and Dialogue (Ontario: University of Waterloo Press, 1989) 15.

53 Historically, there has been an array of land laws dispossessing the Moros of their culturally identified property rights. This began with the Land Registration Act 496 of November 6, 1902 under the American Colonial Administration which required registration and titling of all lands occupied by private individuals and corporations. It fundamentally declared null and void past existing Moro and Lumad indigenous land tenure arrangements. This was followed by the April 4, 1903 Act 718 nullifying all land grants from Moro Sultans or Datus and chiefs of non-Christian tribes without prior government authority and consent. The Philippine Commission subsequently passed Public Land Act 926 on October 7, 1903 permitting each person to acquire a homestead land of 16 hectares and every corporation to claim titled land of 1,024 hectares. Two decades later, this Act was amended by Act 2878 expanding homesteaders to 24 hectares and specifying for non-Christians the right to acquire land not exceeding 10 hectares. On November 7, 1936, the Land Act was again amended through Commonwealth Act 41 reverting from 24 to 16 hectares for Christians and further reducing homestead rights from 10 to 4 hectares for non-Christians. See "Philippine Human Development Report 2002", cited in Social Assessment of Conflict-Affected Areas, World Bank (2003).

54 Lily F. Fetalsana, The Holy War Concept in the Conquest Traditions in Joshua 1-11 and Judges 1:1-2:5 and its Implications for Liberation Movements in the Philippines (a thesis presented to the Faculty of the South East Asia Graduate School of Theology in partial fulfillment of the requirements for the degree Master of Theology, 1999) 128-163. 
56 Julkipli Wadi, The Moro Struggle and the Tenets of Islam in the Philippines (The Hague, the Netherlands: Institute of Social Studies, 2008) 149.

57 Ibrahim Migdal, Muslim Perspective of the Mindanao Problem (Quezon City: Kasarinlan, 1996) 6-37.

58 See International Crisis Group, The Philippines: After the Maguindanao Massacre (Jakarta \& Brussels: International Crisis Group, 2009).

59 Raymund Jose G. Quilop, "The Uneasy and Costly Road to Peace in Mindanao", Panorama (March 2000) 21.

60 Martin Luther King, Jr., The Measure of Man (Philadelphia: Fortres, 1959) 9. 